\title{
New Normal Policy: Factors of Revisit Intention on Green Tourism Karimunjawa
}

\author{
Robetmi Jumpakita Pinem ${ }^{1}$, Iskandar Ahmaddien ${ }^{2}$, Dinalestari Purbawati ${ }^{3}$, Reni Shinta Dewi ${ }^{4}$, \\ Sari Listyorini ${ }^{5}$ \\ \{robetmi@lecturer.undip.ac.id ${ }^{3}$ \} \\ Universitas Diponegoro, Indonesia ${ }^{1,3,4,5}$ \\ Universitas Sangga Buana, Indonesia ${ }^{2}$
}

\begin{abstract}
This research aims to see how past experiences influence the intention to return to Karimunjawa when the New Normal Policy is enacted. Coronavirus (Covid-19) Pandemic has indeed had an impact on all sectors in Indonesia. One of the most affected is the tourism sector because of the prohibition on gathering and reducing physical contact with other people. Indonesia is undergoing a new normal and tourism has started to carry out activities. Green tourism is one of the tours offered in Karimunjawa Island which is visited by many domestic and foreign tourists. Tourists will be made gradually even though the Karimunjawa tourist spot is opened. The closure of tourist visits to Karimunjawa is indeed very impactful for people who depend on the tourism sector for their livelihoods. Such as travel agencies, homestays and those related directly and indirectly to Karimunjawa tourism activities. The amount of Tourist Experience, Destination Image and Perceived Value for the exogenous latent variable revisit intention is shown by the value of $\mathrm{R}$ square (R2), the value of $\mathrm{R}$ square is 0.86 indicating the contribution / influence of tourist experience, destination image and perceived value on revisit intention of $86.0 \%$, the rest amounting to $14.0 \%$ influenced by other factors.
\end{abstract}

Keywords: New Normal Policy, Revisit, Intention, Green Tourism

\section{Introduction}

The world is experiencing a very big crisis and has a tremendous impact on human life. The emergence of the Covid-19 at the end of 2019 and starting to spread to many countries in early 2020 has made a major change in human life in almost all countries in the world. Indonesia is one of the countries affected by the Covid-19. Since early 2020, Indonesia has entered a period to guard against the entry of the Covid-19 into Indonesia. The impact of the Covid-19 has indeed had an impact on all sectors in Indonesia. One of the most affected is the tourism sector because of the prohibition on gathering and reducing physical contact with other people. Indonesia is indeed experiencing a difficult time because the number of positive Covid-19 continues to increase while the vaccine has not been found. This unsafe condition has made many considerations to reopen all community activities to normal times.

The government has indeed imposed a policy of not carrying out activities that are crowd-gathering. Many discuss whether health or economy comes first. If health comes first, it means that economic activities must stop and the government focuses on healing patients and people do not have activities outside the home. If the economy takes precedence, it means that people are free to carry out activities outside the home that have the potential to endanger 
the health or lives of the community. The community does need both at the same time, so the government must make policies that can run both simultaneously.

The new normal policy is a policy made to take the middle path, which keeps the economy running and health is guaranteed. The New Normal policy can be the right one for the current conditions which can provide a solution for the conditions of the people who are severely affected by the Covid-19. This condition has made several business sectors have started moving again after being stopped for a while because the victims of this pandemic continued to increase. The tourism sector is one of the sectors that is greatly affected because of the prohibition on crowds or being in a location where physical touch can occur. Karimunjawa is one of the unspoiled tourist attractions and protects the environment because Karimunjawa tourist attractions are one of the tourist attractions that pamper visitors with beach tourism activities, underwater tours, mangrove forests and other activities that can be enjoyed by visitors.

The spread of Covid-19 is indeed very dangerous because more and more urban districts are in the red zone. Karimunjawa National Park tourism object was closed following the Circular (SE) of the Minister of Environment and Forestry Number SE.1/MENLHK/SETJEN.1/3/2020 dated 15 March 2020 concerning Prevention of the Spread of Covid-19 (Kompas.com, 2020). This closure is because it can endanger the local community so it needs to be closed temporarily. Usually, most tourists enter Karimunjawa through Jepara Regency and Semarang City. Currently the two entrances to Karimunjawa are in the red zone so that it is a danger to the local community if it is opened to the public.

\section{Literature Review}

\subsection{Customer Experience}

Captions should be typed in 9-point Times. They should be centered above the tables and flush left beneath the figures. When consumers use a service, it will form an experience for an event that consumers experience. This experience arises as a result of consumer interactions with the services used. According to Agustina [1] customer experience is an experience that consumers experience regarding a company's products or services. Another definition states that customer experience is the interaction between customers, products, services and companies. This incident certainly caused a reaction that was also personal in nature and implied consumer involvement at different levels rationally, emotionally, sensory, physically and spiritually [2]. Schmitt [3] states that experience can be understood by senses, emotions, perceptions, consumer behavior for a product or service.

It is important for companies to manage their services in order to create experiences that match consumer expectations. When someone has a good experience with a service, they are more likely to tell and recommend to others. Conversely, if the experience obtained is bad, then someone will show anger and may report the bad experience [4]. So, it is quite risky if the service is unsatisfactory and not well received by consumers. Schmitt [3] states that there are five elements in customer experience, namely behavioral experience, cognitive experience, affective experience, sensory experience, and social experience. 


\subsection{Destination Image}

Echtner \& Brent Ritchie in Kurniawan [5] states that destination image simply refers to the impression of a place or one's perception of a certain area. According to Ecthner and Brent Ritchie in Kurniawan [5], there are four components of the destination image, namely functional characteristic attributes, holistic functional characteristics, psychological characteristics attributes, and psychological-holistic characteristics.

\subsection{Perceived Value}

Perceived value is the consumer's general value perception of product/service objectives based on perception received and felt [6]. Perceived value is also related to all perceptions about the value received during the trip based on tour service plans [6]. Perceived value too opinions about money, quality, benefits, and social psychology in assessing a products or services [7].

\subsection{Revisit Intention}

Building a tourism-based business is not easy because it is necessary to provide adequate facilities, maximum service and can create an impression on the minds of consumers. It is important for a company to maintain the level of customer visits so that the business can grow and run continuously. Usually, a tourist attraction will find it easier to attract new people who have never visited it than it is before. So that companies also need to pay attention to factors that can encourage old tourists to visit again (revisit intention).

Revisit Intention is an activity to repeat his visit to a destination [8]. In line with this definition, Zhang in Siregar et al. [9] states that Revisit intention is the interest to visit again which is reflected in customer satisfaction and loyalty to a place. Revisit intention is usually influenced by several variables such as promotions, prices, products, facilities, images and services that tourists get while visiting. If tourists feel happy and satisfied about these variables in a tourist attraction, they tend to give recommendations to other people and make a return visit [8]. Conversely, if you feel unhappy or uncomfortable, you tend not to come back. This feeling of pleasure and satisfaction will make consumers maximize their experience while receiving service and choose to return for the facilities and souvenirs of the place [10].

\section{Method}

This research aims to see how past experiences influence the intention to return to Karimunjawa when the New Normal Policy is enacted. This research will be carried out with mix methods research, which is a combination of qualitative and quantitative approaches. Qualitative is done by interviewing several related parties who know about Karimunjawa tourism. For quantitative use a questionnaire collected from respondents who had visited Karimunjawa before Covid-19 occurred. Respondents will be asked first that they have traveled before and continue to fill out a questionnaire to ask whether there is any intention to revisit Karimunjawa Island. The population of the study were those who had traveled to Karimunjawa Island and the sampling technique was purposive sampling which was asked through visitor data recorded in travel agents and selected in part to represent the population around 75 respondents. The data collected from respondents was done online because the 
conditions of Covid-19 were not yet conducive and the data collected would later be processed using Lisrel software to find out the results.

\section{Results and Discussion}

\subsection{Demographics}

Respondent data in this study were as many as 75 people. If divided by gender, there were 34 male respondents $(45 \%)$ and a larger number, 41 female respondents $(55 \%)$. The respondents in this study were scattered from various regions such as Semarang, Salatiga and other cities on the island of Java.

\subsection{Analysis of the Validity and Reliability of Confirmatory Factors}

Confirmatory factor analysis aims to test the un-dimensionality of the forming indicators of each latent variable. The following are the results of the confirmatory factor analysis of each model.

Table 1. Confirmatory Factor Analysis (CFA)

\begin{tabular}{|c|c|c|c|c|c|c|}
\hline Variable & Indicator & $\lambda$ & $\lambda^{2}$ & e & CR & VE \\
\hline \multirow{6}{*}{ Tourist Experience } & $\mathrm{X} 1$ & 0.71 & 0.50 & 0.03 & \multirow{6}{*}{0.96} & \multirow{6}{*}{0.80} \\
\hline & $\mathrm{X} 2$ & 0.57 & 0.32 & 0.08 & & \\
\hline & X3 & 0.80 & 0.64 & 0.14 & & \\
\hline & $\mathrm{X} 4$ & 0.65 & 0.42 & 0.36 & & \\
\hline & $\mathrm{X} 5$ & 0.65 & 0.42 & 0.04 & & \\
\hline & X6 & 0.74 & 0.55 & 0.07 & & \\
\hline \multirow{4}{*}{ Destination Image } & $\mathrm{X} 7$ & 0.67 & 0.45 & 0.15 & \multirow{4}{*}{0.95} & \multirow{4}{*}{0.84} \\
\hline & $\mathrm{X} 8$ & 0.68 & 0.46 & 0.04 & & \\
\hline & $\mathrm{X} 9$ & 0.50 & 0.25 & 0.08 & & \\
\hline & $\mathrm{X} 10$ & 0.80 & 0.64 & 0.07 & & \\
\hline \multirow{7}{*}{ Perceived Value } & $\mathrm{X} 11$ & 0.53 & 0.28 & 0.09 & \multirow{7}{*}{0.95} & \multirow{7}{*}{0.75} \\
\hline & $\mathrm{X} 12$ & 0.68 & 0.46 & 0.24 & & \\
\hline & $\mathrm{X} 13$ & 0.71 & 0.50 & 0.30 & & \\
\hline & $\mathrm{X} 14$ & 0.78 & 0.61 & 0.07 & & \\
\hline & $\mathrm{X} 15$ & 0.67 & 0.45 & 0.04 & & \\
\hline & $\mathrm{X} 16$ & 0.59 & 0.35 & 0.06 & & \\
\hline & $\mathrm{X} 17$ & 0.59 & 0.35 & 0.21 & & \\
\hline \multirow{6}{*}{ Revisit Intention } & $\mathrm{Y} 1$ & 0.61 & 0.37 & 0.09 & \multirow{6}{*}{0.91} & \multirow{6}{*}{0.63} \\
\hline & Y2 & 0.59 & 0.35 & 0.37 & & \\
\hline & Y3 & 0.61 & 0.37 & 0.42 & & \\
\hline & $\mathrm{Y} 4$ & 0.57 & 0.32 & 0.30 & & \\
\hline & Y5 & 0.82 & 0.67 & 0.22 & & \\
\hline & Y6 & 0.67 & 0.45 & 0.06 & & \\
\hline
\end{tabular}

Table 1 shows that the loading factor for each construct indicator is greater than 0.5 . This means that each indicator is declared valid in forming variable constructs. Then CR (construct 
reliability) must be above 0.7 and VE (variance extracted) must be above 0.5 , so it can be concluded that the variable construct has good construct validity and reliability.

\subsection{Full Model Testing}

The full structural model estimation analysis illustrates the relationship between latent variables and can be done if the measurement model has been analyzed through confirmatory factor analysis. This is because each indicator can be used to define a latent construct. The full structural model estimation results are presented in the following figure.

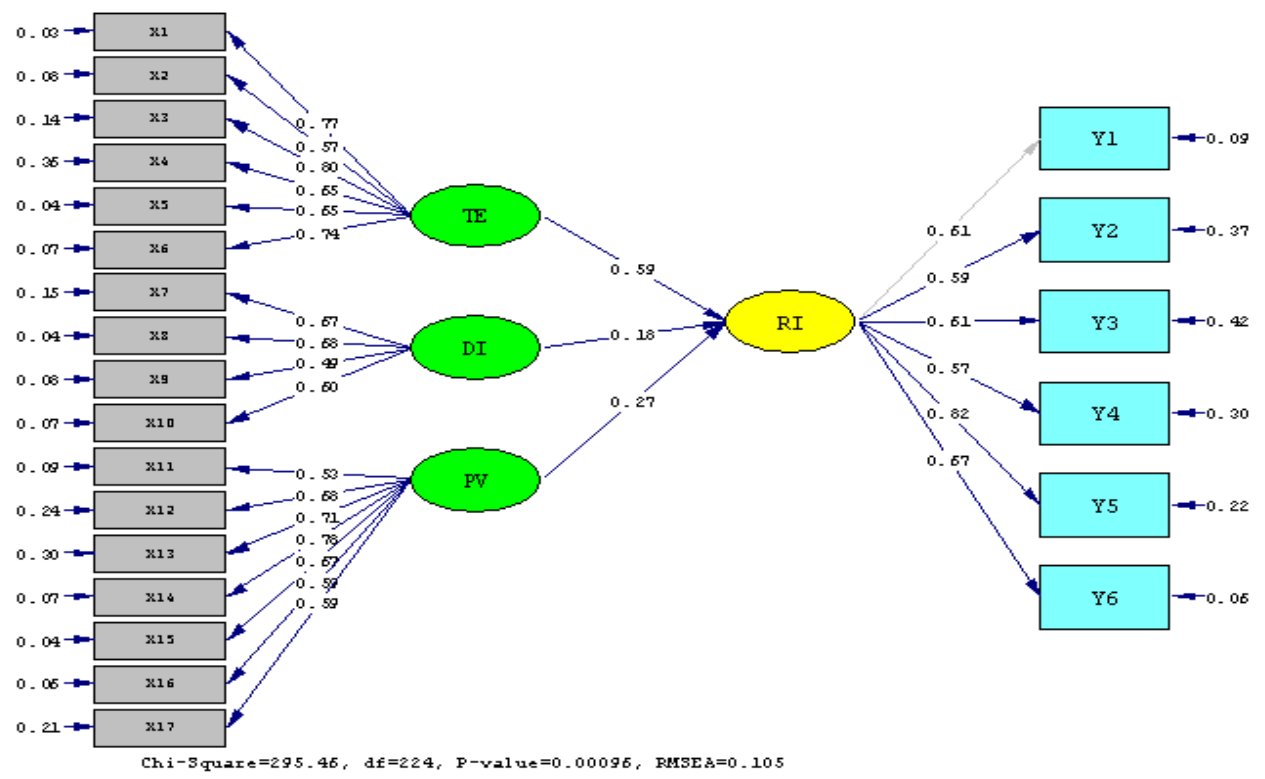

Figure 1. The results of the full structural model.

Test results on the structural equation are presented in the image above. SEM model testing is carried out by two kinds of tests, namely the suitability of the model and the significance of the causality through the regression coefficient. SEM model testing is used to see the feasibility of the model or the suitability of the model. The model suitability indices used were not different from the indices in the confirmatory factor analysis. Based on the results of the model above, the chi-square value $=295.46 \mathrm{df}=224$, $\mathrm{p}$-value $=0.0096$ and RMSEA $=0.105$. To find out whether the structural model developed has been supported by data, a goodness of fit test is performed. The following are the results of the goodness of fit test on the structural model.

Table 2. Goodness of Fit Research Model Testing

\begin{tabular}{|c|c|c|c|}
\hline Good of Fit Index & Result & Critical value & Conclusion \\
\hline Cisquare/DF & 1,32 & $2<\mathrm{X}^{2} / \mathrm{df}<5$ & Bad Fit \\
\hline CFI & 0.91 & $\geq 0,9$ & Good Fit \\
\hline GFI & 0.53 & $\geq 0,9$ & Bad Fit \\
\hline AGFI & 0.42 & $\geq 0,9$ & Bad Fit \\
\hline
\end{tabular}




\begin{tabular}{|c|c|c|c|}
\hline RMSEA & 0.10 & $\leq 0.08$ & Bad Fit \\
\hline RMR & 0.05 & $\leq 0.05$ & Good Fit \\
\hline
\end{tabular}

In the table above, the test results for the fit model see the values of Cisquare / DF, CFI, GFI, AGFI, RMSEA and RMR. This study has met the criteria because the value tested for 2 out of 6 values is good so that the model is declared feasible for further processing.

\subsection{Hypothesis Testing}

The following is the Loading Factor generated by the structural model, where if the calculated $\mathrm{T}$ value is greater than the $\mathrm{T}$ table value, it is significant:

$$
\begin{array}{clll}
\mathrm{RI}=0.59 * \mathrm{TE}+0.18^{*} \mathrm{DI}+ & 0.27 * \mathrm{PV}, \text { Errorvar }=0.14, \mathrm{R}^{2}=0.86 \\
(0.21) & (0.12) & (0.17) & (0.061) \\
2.78 & 1.55 & 1.57 & 2.35
\end{array}
$$

From the results above, it can be seen that the coefficient of the exogenous latent variable of Tourist Experience on the exogenous latent variable of Revisit Intention is 0.59, indicating a positive direction of relationship between Tourist Experience and Revisit Intention, meaning that when Tourist Experience is good, Revisit Intention will be good. The $t$ count value of 2.78 is greater than the specified critical limit, namely \pm 1.96 , so that $\mathrm{H} 0$ is rejected, which means that there is an influence of Tourist Experience on the exogenous latent variable Revisit Intention. The coefficient of the exogenous latent variable Destination Image on the exogenous latent variable Revisit Intention is 0.18 , indicating a positive direction of the relationship between Destination Image and Revisit Intention, meaning that when the Destination Image is good, Revisit Intention will be good.

The $t$ value of 1.55 is smaller than the specified critical limit, which is \pm 1.96 , so that $\mathrm{H} 0$ is accepted, which means that there is no influence of Destination Image on the exogenous latent variable Revisit Intention. The coefficient of the exogenous latent variable Perceived Value for the exogenous latent variable Revisit Intention is 0.27 , indicating a positive direction of relationship between Perceived Value and Revisit Intention, meaning that when the Perceived Value is good, Revisit Intention will be good. The $t$ count value of 1.57 is smaller than the specified critical limit, which is \pm 1.96 , so that $\mathrm{H} 0$ is accepted, which means that there is no influence of Perceived Value on the exogenous latent variable Revisit Intention.

The amount of Tourist Experience, Destination Image and Perceived Value for the exogenous latent variable Revisit Intention is shown by the value of R square (R2), the value of $\mathrm{R}$ square is 0.86 indicating the contribution/influence of Tourist Experience, Destination Image and Perceived Value on Revisit Intention of $86.0 \%$, the rest amounting to $14.0 \%$ influenced by other factors.

Currently conditions are at an unfavorable time due to the Covid-19 which is still not over. Starting from the tourist attraction of Karimunjawa National Park being closed following the Circular (SE) of the Minister of Environment and Forestry Number SE.1/MENLHK/SETJEN.1.3/2020 dated 15 March 2020 concerning Prevention of the Spread of Covid-19 (Kompas.com, 2020). This is a condition where it is important to know that currently to keep Karimunjawa Island free from Covid-19 so that temporary closure is considered the best solution at this time to avoid bad things for the people in Karimunjawa. 
Based on the results of interviews with the Karimunjawa National Park Agency which has the authority over the Karimunjawa National Park, this pandemic condition actually brings benefits to the national park because it reduces the damage caused by the crowd of visitors who come to Karimunjawa. The National Park Agency is tasked with preserving the Karimunjawa National Park even though it is used for tourism activities, it keeps the national park intact.

One of the policies taken is for natural tourism activities to be given special areas for tourism actors and tourists both domestic and abroad. Not all islands in the national park can be visited by tourists. Special rooms and islands are given that can be used as tourist attractions. So, this is one of the steps to maintain sustainability or preserve the Karimunjawa National Park from damage by human activities. The Karimunjawa tourism office said that there was already a permit to operate again with permission from the Ministry of Environment and now it could start but the problem was that one of the conditions for entering the national park was that the entrance had to be a green zone.

The entrance to Karimunjawa is currently from Jepara Regency and Semarang City and both are currently in a red zone so it is still pending to reopen Karimunjawa tourist attractions. Karimunjawa as a tourist spot is indeed given a special room to be managed by the tourism sector. As we know, Karimunjawa is one of the natural tourist destinations that is in great demand by domestic and foreign tourists. The reopening is one that some nature tourism lovers have been waiting for. Visitors who wish to visit Karimunjawa will soon be able to visit because there has been a decision from the Minister of the Environment to reopen and open these tourist attractions to be limited in advance to protect the risk of Coronavirus (Covid1-19) Pandemic.

Tourists will be made gradually even though the Karimunjawa tourist spot is opened. Every week will be allowed 100 visitors and progress will be seen if conditions are good and no bad things happen, the capacity of the number of visitors will be increased again and will continue until normal conditions later without any restrictions on the number of visitors to Karimunjawa. The closure of tourist visits to Karimunjawa is indeed very impactful for people who depend on the tourism sector for their livelihoods. Such as travel agencies, homestays and those related directly and indirectly to Karimunjawa tourism activities. data collected would later be processed using SPSS software to find out the results.

\section{Conclusion}

Coronavirus (Covid1-19) Pandemic has indeed had an impact on all sectors in Indonesia. One of the most affected is the tourism sector because of the prohibition on gathering and reducing physical contact with other people. This unsafe condition has made many considerations to reopen all community activities to normal times. The government has indeed imposed a policy of not carrying out activities that are crowd-gathering. The tourism sector is one of the sectors that is greatly affected because of the prohibition on crowds or being in a location where physical touch can occur. Karimunjawa is one of the unspoiled tourist attractions and protects the environment because Karimunjawa tourist attractions are one of the tourist attractions that pamper visitors with beach tourism activities, underwater tours, mangrove forests and other activities that can be enjoyed by visitors.

The amount of Tourist Experience, Destination Image and Perceived Value for the exogenous latent variable Revisit Intention is shown by the value of $R$ square (R2), the value of $\mathrm{R}$ square is 0.86 indicating the contribution/influence of Tourist Experience, Destination 
Image and Perceived Value on Revisit Intention of $86.0 \%$, the rest amounting to $14.0 \%$ influenced by other factors.

Karimunjawa National Park, such a pandemic condition, actually brings benefits to the national park because it reduces the damage caused by the high number of visitors who come to Karimunjawa. The National Park Agency is tasked with preserving the Karimunjawa National Park even though it is used for tourism activities, it keeps the national park intact. Not all islands in the national park can be visited by tourists. Given a special room and certain islands that can be used as tourist attractions

Tourists will be made gradually even though the Karimunjawa tourist spot is opened. Every week will be allowed 100 visitors and progress will be seen if conditions are good and no bad things happen, the capacity of the number of visitors will be increased again and will continue until normal conditions later without any restrictions on the number of visitors to Karimunjawa. The closure of tourist visits to Karimunjawa is indeed very impactful for people who depend on the tourism sector for their livelihoods. Such as travel agencies, homestays and those related directly and indirectly to Karimunjawa tourism activities.

\section{References}

[1] N. K. W. Agustina, "The Influence of Customer Experiencê̂A to Revisit Intenton in Pandawa Beach Attraction,” J. Soc. Sci. Res., pp. 634-638, 2018.

[2] R. G. Pranoto, "Analisa Pengaruh Customer Experience Terhadap Customer Satisfaction Pada Konsumen Di Rosetta's Cafe \& Resto Surabaya,” J. Strateg. Pemasar., vol. 3, no. 1, pp. 1-9, 2015.

[3] B. Schmitt, "Experiential marketing: A new framework for design and communications," Des. Manag. J. (Former Ser., vol. 10, no. 2, pp. 10-16, 1999.

[4] P. Kotler and K. L. Keller, "Manajemen Pemasaran, Edisi 13," Jakarta: Erlangga, vol. 14, 2009.

[5] C. J. Kurniawan, "Studi Deskriptif Destination Image Kota Malang Menurut Perspektif Wisatawan Surabaya," CALYPTRA, vol. 3, no. 2, pp. 1-15, 2014.

[6] S. M. Rasoolimanesh, N. Dahalan, and M. Jaafar, "Tourists' perceived value and satisfaction in a community-based homestay in the Lenggong Valley World Heritage Site," J. Hosp. Tour. Manag., vol. 26, pp. 72-81, 2016.

[7] Y.-F. Kuo, C.-M. Wu, and W.-J. Deng, "The relationships among service quality, perceived value, customer satisfaction, and post-purchase intention in mobile value-added services," Comput. Human Behav., vol. 25, no. 4, pp. 887-896, 2009.

[8] E. Yuningsih, "Analisis Pengaruh Customer Experience Terhadap Minat Berkunjung Kembali Pada Destinasi Wisata Kota Bogor," J. Visionida, vol. 4, no. 1, pp. 13-22, 2018.

[9] E. Siregar, V. Novita, and D. Mahmudah, "Tourists' Satisfaction and Revisit Intention To Medan, Indonesia," HELD BY, p. 117, 2019.

[10] I. A. I. Dewi and D. Laksmidewi, "Pengaruh Customer Experiences Terhadap Revisit Intention Dengan Mediasi Learning In Museum Dan Visitor Satisfaction Di Museum Wayang,” $J$. Manaj., vol. 12, no. 2, pp. 160-178, 2015. 